Check for updates

Cite this: RSC Adv., 2018, 8, 18800

\title{
Electrochemistry and microbiology of microbial fuel cells treating marine sediments polluted with heavy metals
}

\author{
Syed Zaghum Abbas, ${ }^{a}$ Mohd Rafatullah, (D) *a Norli Ismail ${ }^{a}$ and Farah R. Shakoori ${ }^{\text {b }}$
}

The industrial contamination of marine sediments with chromium, copper and nickel in Penang, Malaysia was addressed with bio-remediation, coupled with power generation, using in situ sediment microbial cells (SMFCs) under various conditions. The efficiency of aerated sediment microbial fuel cells (A-SMFCs) and non-aerated sediment microbial fuel cells (NA-SMFCs) was studied. The A-SMFCs generated a voltage of $580.5 \mathrm{mV}$ between 50 and 60 days, while NA-SMFCs produced a voltage of $510 \mathrm{mV}$ between 60 and 80 days. The cell design point for A-SMFCs was $2 \mathrm{k} \Omega$, while for NA-SMFCs it was $200 \Omega$. In both SMFCs, the maximum current values relating to forward scanning, reverse scanning and oxidation/reduction peaks were recorded on the $80^{\text {th }}$ day. The anode showed maximum additional capacitance on the $80^{\text {th }}$ day (A-SMFC: $2.7 \mathrm{~F} \mathrm{~cm}^{-2}$; and NA-SMFC: $2.2 \mathrm{~F} \mathrm{~cm}^{-2}$ ). The whole cell electrochemical impedance using the Nyquist model was $21 \Omega$ for A-SMFCs and $15 \Omega$ for NA-SMFCs. After glucose enrichment, the impedance of A-SMFCs was $24.3 \Omega$ and $14.6 \Omega$ for NA-SMFCs. After 60 days, the A-SMFCs reduced the maximum amount of $\mathrm{Cr}(\mathrm{VI})$ to $\mathrm{Cr}(\mathrm{III})$ ions $(80.70 \%)$ and $\mathrm{Cu}(\mathrm{II})$ to $\mathrm{Cu}(\mathrm{I})$ ions $(72.72 \%)$, and showed maximum intracellular uptake of $\mathrm{Ni}(\Perp)$ ions $(80.37 \%)$; the optimum remediation efficiency of NA-SMFCs was after 80 days toward $\mathrm{Cr}(\mathrm{VI})$ ions $(67.36 \%), \mathrm{Cu}(I)$ ions $(59.36 \%)$ and $\mathrm{Ni}(I)$ ions (52.74\%). Both SMFCs showed highest heavy metal reduction and power generation at a pH of 7.0. SEM images and 16S rRNA gene analysis showed a diverse bacterial community in both A-SMFCs and NASMFCs. The performance of A-SMFCs showed that they could be exercised as durable and efficient technology for power production and the detoxification of heavy metal sediments. The NA-SMFCs could also be employed where anaerobic fermentation is required.

Received 27th February 2018

Accepted 9th May 2018

DOI: $10.1039 / c 8 \mathrm{ra01711e}$

rsc.li/rsc-advances solidification technology), thermal treatment, bio-chemical stabilization, sediment washing (including chemical leaching/ washing, physical separation and bioleaching), in situ capping, natural attenuation (natural recovery), and waterway confinement (in situ confinement). These are effective but they encounter some considerable drawbacks, such as high energy requirements, excessive chemical utilization and the production of heavy waste sludge in high amounts. ${ }^{4}$ Recently, microbial fuel cell (MFC) systems have been attracting attention as the most promising approach to treat industrial wastewater, including power generation. Sediment microbial fuel cells (SMFCs) or benthic microbial fuel cells (BMFCs) are a particular class of MFCs for electricity generation and sediment remediation, utilizing the electro-potential contrast between oxic and anoxic compartments of SMFCs. ${ }^{5,6}$ The general prototype SMFC consists of an anode enclosed in marine sediment and a cathode positioned in the surface water. Microbes break down the organic and inorganic compounds present in the sediment and release protons and electrons. Electrons are transferred from the anode to the cathode via an outer circuit and protons flow to the cathode terminal from the sediment and fuse with oxygen at the cathode to form water. ${ }^{7,8}$ Reimers et al. ${ }^{9}$ applied
${ }^{a}$ Division of Environmental Technology, School of Industrial Technology, Universiti Sains Malaysia, 11800, Penang, Malaysia. E-mail: mohd_rafatullah@yahoo.co.in; mrafatullah@usm.my; Fax: +60-4-653-6375; Tel: +60-4-653-2111

${ }^{b}$ Department of Zoology, University of the Punjab New Campus Lahore, Pakistan 
for the first time electrodes made up of platinum mesh to generate power from both estuarine and salt-marsh sediments. They used platinum mesh electrodes and so obtained a lower amount of energy and a low rate of sediment remediation.

The marine sediments near Bayan Lepas, Penang, Malaysia are highly contaminated with chromium, copper and nickel. So, in the competitive global environment today, it has become necessary to clean the marine sediment contaminated by industrial wastewater to minimize aquatic pollution in the aquatic ecosystem, which directly affects human health. Thus, in this study, in situ SMFCs were used to remediate Penang marine sediments, coupled with power generation. The main difference in the SMFCs used in this study is that a bigger modeling size was used compared to previous SMFC studies, so optimizing the external parameters of these SMFCs will lead one step closer to SMFC scale-up. The optimization of SMFC parameters ( $\mathrm{pH}$ and external resistance) was investigated through electricity generation and heavy metal reduction with and without cathode aeration, because oxygen is the main parameter that highly affects SMFC performance. ${ }^{\mathbf{1 0}}$ A comparative analysis of the electro-microbiology and biofilm morphology of both types of SMFC was also conducted to understand the effects of the microbial community on the performance of SMFCs.

\section{Experimental section}

\subsection{Sediment sampling}

Sediment (0-20 cm depth) and marine water were sampled from the Bayan Lepas (Pulau Pinang, Malaysia) industrial zone. The sediment was collected using a Ponar-type sampler (86475 Gene Lassere BLVD, 2.4 L, USA). Sediment and water samples were put into clean polycarbonate bottles (Kimax Kimble, Fisher brand) and transported to the research laboratory.

\subsection{Measurement of the physico-chemical parameters of sediment samples}

The chemical and physical characteristics of the sediment samples are presented in Table 1.

Table 1 Physico-chemical properties of sediment collected from the marine stream of Bayan Lepas, Penang, Malaysia

\begin{tabular}{ll}
\hline Parameter & Untreated sediment \\
\hline Color & Dark brown \\
Temperature $\left({ }^{\circ} \mathrm{C}\right)$ & $26-28$ \\
$\mathrm{pH}$ & $6.0-8.0$ \\
Sand $(\%, \mathrm{w} / \mathrm{w})$ & $17.9 \pm 3.2$ \\
Silt $(\%, \mathrm{w} / \mathrm{w})$ & $85.4 \pm 4.0$ \\
Clay $(\%, \mathrm{w} / \mathrm{w})$ & $4.5 \pm 2.7$ \\
Carbon content $(\%, \mathrm{w} / \mathrm{w})$ & $3.0 \pm 1.6$ \\
Water content $(\%, \mathrm{w} / \mathrm{w})$ & $50.5 \pm 2.7$ \\
Electrical conductivity $\left(\mu \mathrm{S} \mathrm{cm}{ }^{-1}\right)$ & $498 \pm 6.11$ \\
Cr(VI) ions $\left(\mathrm{mg} \mathrm{kg}^{-1}\right)$ & $390.3 \pm 3.2$ \\
$\mathrm{Cu}(\mathrm{II})$ ions $\left(\mathrm{mg} \mathrm{kg}^{-1}\right)$ & $480.1 \pm 3.3$ \\
$\mathrm{Ni}(\mathrm{II})$ ions $\left(\mathrm{mg} \mathrm{kg}^{-1}\right)$ & $180.5 \pm 2.5$
\end{tabular}

The $\mathrm{pH}$ was measured using a $\mathrm{pH}$ meter (HACH Sension3 Company, Loveland, Colo, USA) and temperature was measured using a liquid thermometer (GH, ZEAL LTD, London, England) at the time of sediment sampling.

Sand, silt and clay measurements. The percentages of sand, clay and silt were measured via a very common method. About $100 \mathrm{~g}$ of sediment was homogenized through a less than $2 \mathrm{~mm}$ sieve (ASTEAE-11, USA). A straight-sided glass bottle was filled to about $1 / 3$ full with sieved sediments. Distilled water was added to fill about $3 / 4$ of bottle, and the bottle was capped and shaken vigorously for 10 minutes to mix everything and make sure that no sediment was clinging to the bottom of the bottle. The bottle was placed on a desk, where it was undisturbed for several weeks. After 1-2 minutes, a first reading was taken with a wax pencil marking the level of sediment in the bottle; this represented the sand. A second reading was noted after 2 hours between 2 lines, which indicated the silt. After 2 weeks, a third reading was taken at the bottom of the bottle, which denoted the clay. The noted levels of sand, silt and clay were divided by the total level of sediment and multiplied by 100 to give the percentages of sand, silt and clay.

Carbon content measurement. For the measurement of carbon content, about $10 \mathrm{~g}$ of sediment sample was sieved and ground with a pestle. A crucible was used to dry this sediment sample at $60{ }^{\circ} \mathrm{C}$. A new crucible was weighed and denoted as $m_{\text {cruc }}$. About $1 \mathrm{~g}$ of the dried sediment sample was placed in this crucible and weighed and denoted as $m_{\text {initial }}$. This crucible was put into a furnace at $1000{ }^{\circ} \mathrm{C}$ overnight for the destruction of the carbon content. Then the crucible was cooled and weighed and denoted as $m_{\text {final }}$. Then:

$$
m_{\mathrm{tc}}=\left(m_{\text {initial }}-m_{\mathrm{cruc}}\right)-m_{\mathrm{final}} \times 100
$$

where $m_{\mathrm{tc}}$ is the total carbon content.

Water content measurement. An evaporating dish was washed, placed into a drying oven at $105{ }^{\circ} \mathrm{C}$ for 30 minutes, cooled to room temperature in a desiccator and weighed $\left(m_{\mathrm{a}}\right)$. Then $0.5 \mathrm{~g}$ of sediment was put into the evaporating dish and again its weight was measured $\left(m_{\mathrm{b}}\right)$. This evaporating dish with sediment was placed into a drying oven at $105{ }^{\circ} \mathrm{C}$ overnight. The evaporating dish was cooled again to room temperature in the closed desiccator and weighed $\left(m_{\mathrm{c}}\right)$. The following equation was used to calculate the water content:

$$
W_{\mathrm{wc}}=\frac{m_{\mathrm{b}}-m_{\mathrm{c}}}{m_{\mathrm{b}}-m_{\mathrm{a}}} \times f
$$

where: $W_{\mathrm{wc}}=$ the water content in the sediment sample as a percentage; $m_{\mathrm{a}}=$ the mass of the empty evaporating dish; $m_{\mathrm{b}}$ $=$ the mass of the evaporating dish with the sediment sample before drying in an oven; $m_{\mathrm{c}}=$ the mass of the evaporating dish with the sediment sample after drying in an oven at $105^{\circ} \mathrm{C}$; and $f=$ is a conversion factor, where $f=100$.

Electrical conductivity (EC). The electrical conductivities of sediment samples were measured using an EC meter (ESEL, Ambala, India). The probes of the EC meter were firstly calibrated with standard solutions (with known conductivity). The sediment sample was put into an SMFC, then the probe tips of 
the EC meter were inserted into the sediment; after waiting until the reading on the EC meter was stabilized, this reading was noted as the electrical conductivity.

\subsection{SMFC design and operation}

Three replicas of both A-SMFCs and NA-SMFCs were constructed using plexiglass. The SMFCs were firstly nourished with wet sediments (767 g) and then this was overlaid with $200 \mathrm{~mL}$ of marine water. For every SMFC, fifteen linked pieces of graphite plate $(15$ anodes +1 cathode $=16: 3 \times 1 \mathrm{~cm}$ for each, giving a total area of $48 \mathrm{~cm}^{2}=0.0048 \mathrm{~m}^{2}$ ) were vertically embedded into the sediment, with $1 \mathrm{~cm}$ gaps, as an anode array. Another graphite plate with the same dimensions was used as a cathode, located $6 \mathrm{~cm}$ under the upper surface of the water. The cathode and anode array were linked with rubber copper sealed wire, to avoid leakage and corrosion. All bonding spots were covered with silicone rubber. The overall dimensions of the SMFCs were $8.7 \mathrm{~cm}$ (width) $\times 17.6 \mathrm{~cm}$ (length), as shown in Fig. 1.

The lengths of the cathode and anode compartments were $9.6 \mathrm{~cm}$ and $8.0 \mathrm{~cm}$, respectively. The gap between the anode and cathode was $8 \mathrm{~cm}$. A commercially available air pump (JAD Aquarium, Electrical Product Co. Ltd.) was employed to supply air near the bottom of the cathode, $8 \mathrm{~cm}$ from the top water level in all aerated sediment microbial fuel cells (A-SMFCs), but air was not introduced into the non-aerated microbial fuel cells (NA-SMFCs). The NA-SMFCs were operated inside an anaerobic chamber and their lids were sealed with glass binding glue and parafilm. A $3 \mathrm{~g} \mathrm{~L}^{-1}$ solution of glucose $(10 \mathrm{~mL})$ was added to the overlying marine water to overcome the loss of water through evaporation, and this was blended with a steel spatula to obtain a homogenized sediment mixture. The SMFC voltages were monitored using a digital wireless data acquisition system (FLIR systems, Extech Instruments, Model EX5422, Inc., USA) linked to a PC.
The following formulas were used. Ohm's law $(R=V / I)$ was used to calculate the current, where $R$ is the external resistance $(\Omega)$ and $V$ is the cell voltage $(\mathrm{mV})$. Power was calculated using $P$ $=V I$. The optimum power density was recorded by altering the external resistance from $60 \Omega$ to $2 \mathrm{k} \Omega$, with 15 min intervals for voltage stabilization. The following formulas were used to measure the current density and power density, where $(J)$ is the current density and $(P)$ is the power density. The slope of the polarization curve was used to calculate the internal resistance of each SMFC. ${ }^{11}$

$$
\begin{gathered}
(J)=\frac{I}{A} \\
(P)=\frac{V^{2}}{R A}
\end{gathered}
$$

\subsection{Cyclic voltammetry}

Current peaks occurred on the voltammograms if constituents were reduced or oxidized between potential sweeps of the biomass. Each constituent that could be reversibly reduced or oxidized had a peak on both the lower and upper curves. If one of the peaks faded, the component could be considered as stably reduced or oxidized. When this method was applied to a bacterial culture, peaks could develop for both cellular components, such as periplasm and cytochromes, and excreted redox mediators, like pyocyanin. The oxidation reduction reactions at electrodes were characterized via cyclic voltammogram studies (Metrohm PGSTAT12 Autolab Eco Chemie). The electrode surface current response at a scan rate of $25 \mathrm{~V} \mathrm{~s}^{-1}$ (per 5 scans) between -0.8 and $+0.8 \mu \mathrm{A}$ was measured in an unstirred solution. The working electrode was the anode and the counter electrode was the cathode, with $\mathrm{Ag} / \mathrm{AgCl}$ as the reference electrode.

The specific capacitance, $C_{\mathrm{m}}\left(\mathrm{F} \mathrm{cm}^{-2}\right)$, defined as the integration over the entire set of data per unit area of the cathode
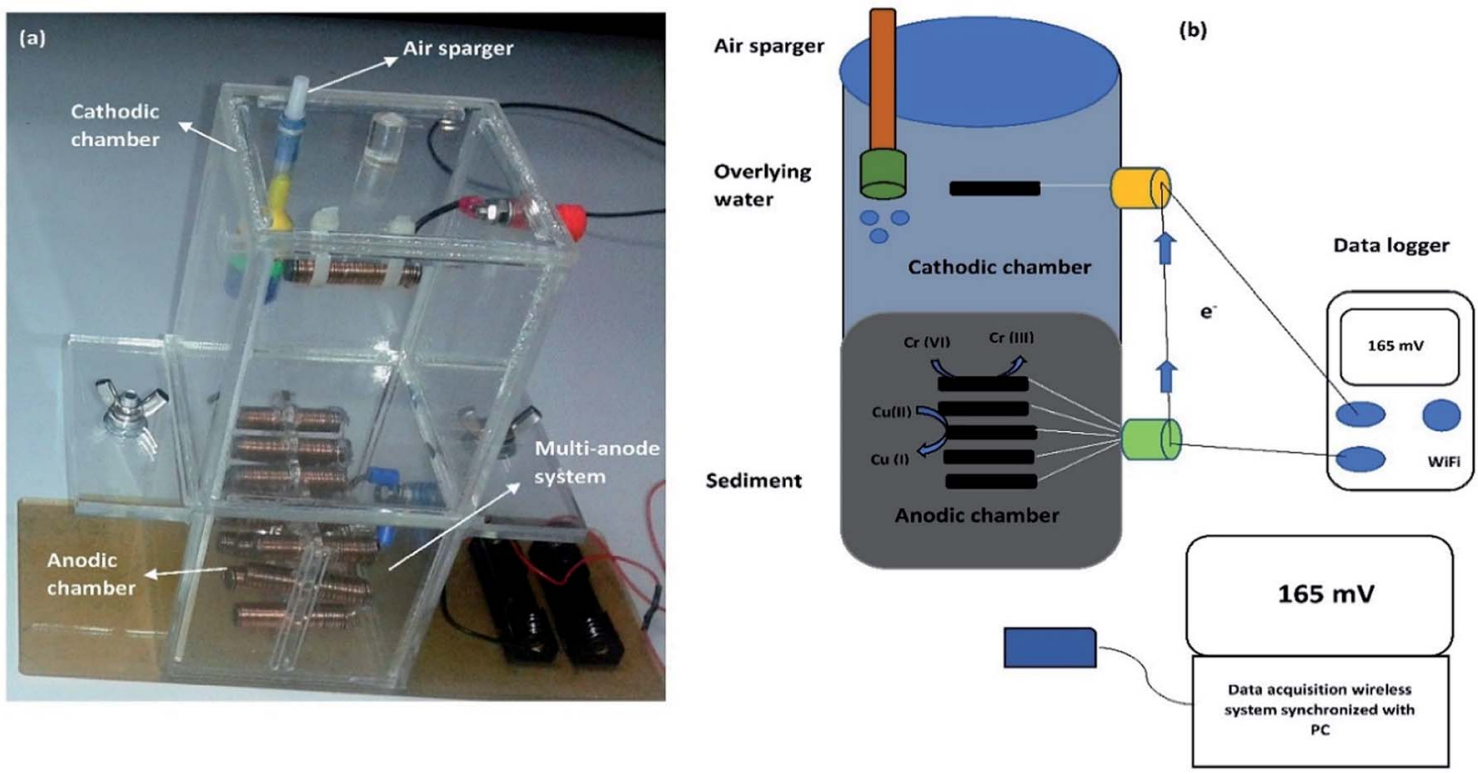

Fig. 1 A two chamber SMFC: (a) a prototype model of an SMFC; and (b) the operational mechanism of an SMFC. 
and anode, is calculated from CV (cyclic voltammetry) according to the equation as follows:

$$
C_{\mathrm{m}}=\frac{Q_{\mathrm{a}}+Q_{\mathrm{c}}}{\frac{2 A \Delta E}{d}}
$$

where $Q_{\mathrm{c}}(\mathrm{C})$ and $Q_{\mathrm{a}}(\mathrm{C})$ are sums of the cathodic and anodic volumetric charges in both SMFCs and $\Delta E(\mathrm{~V})$ is the potential drop range during CV. $A$ is the surface area of the anode $\left(48 \mathrm{~cm}^{2}\right)$ and cathode $\left(3 \mathrm{~cm}^{2}\right) . D$ is the distance between the anode and cathode $(8 \mathrm{~cm})$.

\subsection{Electrochemical impedance spectroscopy}

Electrochemical impedance spectroscopy (EIS) was conducted by employing a Gamry Instruments Group Metrohm PGSTAT12 Autolab Eco Chemie. Two kinds of EIS data analysis were applied: a two-electrode configuration and a three-electrode configuration. EIS has been determined to measure resistances at the electrolyte/solution cathode and anode in SMFC systems. The accurate measurement of anode and cathode resistances for whole cell measurements was backed by singleelectrode analysis in a symmetric ECM. EIS with a three electrode configuration gave the measurements for SMFCs. Wholecell EIS measurements were carried out in a SMFC on days 30, 60, 90 and 120 to characterize the turnover in terms of electrochemical parameters as an outcome of biocatalyst enhancement. The frequency range was $100 \mathrm{kHz}$ to $100 \mathrm{mHz}$ for EIS analysis. To prevent biofilm detachment and to minimize disruption to the steady state of the system, the perturbation AC amplitude was $1 \mathrm{mV}$. About $20 \mathrm{~min}$ was required, with the amplitude of every scan range $(0.5-0.1 \mathrm{~Hz})$, for the completion of each spectrum. All EIS analysis was performed in the operative mode of the SMFC, such as when the SMFC was connected to an external resistance.

\subsection{Heavy metal remediation}

About $250 \mathrm{~g}$ of sediments was incubated at $100{ }^{\circ} \mathrm{C}$ for drying before the operation of the SMFCs. ${ }^{12}$ Fine sediment powder was made using a mortar, and a sieve was used to filter it after drying; then, to prevent moisture absorption, the sediment powder was placed into a desiccator. Teflon tubes were filled with about $250 \mathrm{~g}$ of fine sediment powder, and also $2 \mathrm{~mL}$ of $\mathrm{HNO}_{3}, 5 \mathrm{~mL}$ of $\mathrm{H}_{2} \mathrm{SO}_{4}$, and $1 \mathrm{~mL}$ of $\mathrm{HF}$ were added. After tight capping, the Teflon tubes were spun in a microwave instrument (Anton Paar $/ \alpha$ analytical, Multiwave 3000, USA) for $2 \mathrm{~h}$. Whatman filter paper (Sartorius Stedim, Biotech) was used to filter the sediment samples in the plastic bottles and lastly they were topped up with $\mathrm{HCl}(75 \%)$ and stored at $4{ }^{\circ} \mathrm{C}$. Then an atomic absorption spectrophotometer (A3G graphite furnace atomic absorption spectrometer, USA) was used to detect the quantification of possible heavy metals and they were analyzed with reference to Sediment Management Standards USA, ${ }^{13}$ as presented in Table 3. X-ray photoelectron spectroscopy (XPS) (Kratos Analytical, a Shimadzu group company, UK) was used to detect heavy metal speciation before and after SMFC operation. Then, raw sediment samples were placed into A-SMFCs and NA-
SMFCs for approximately 120 days. Every 20 days, about $500 \mathrm{mg}$ of sediment sample was extracted and stored at $4{ }^{\circ} \mathrm{C}$. AAS was used to analyze the heavy metal concentrations in these stored sediment samples and eqn (6) was used to calculate the remediation efficiency (RE, \%), ${ }^{13}$ where the initial heavy metal concentration before SMFC operation was denoted as $\mathrm{HM}_{\mathrm{i}}$ and the heavy metal concentration after SMFC operation was denoted as $\mathrm{HM}_{\mathrm{OP}}$, with a range of external resistance from $60 \Omega$ to $2 \mathrm{k} \Omega$.

$$
\mathrm{RE}=\frac{\mathrm{HM}_{\mathrm{i}}-\mathrm{HM}_{\mathrm{op}}}{\mathrm{HM}_{\mathrm{i}}} \times 100
$$

\subsection{Effect of $\mathrm{pH}$ on heavy metal reduction and power generation}

To show the effects of $\mathrm{pH}$ on heavy metal reduction and power generation, both A-SMFCs and NA-SMFCs were operated over $\mathrm{pH}$ ranges of 1.0-13.0. A-SMFCs and NA-SMFCs were operated at their optimal external resistances, $2 \mathrm{k} \Omega$ and $200 \Omega$, respectively. The voltage generation was noted at each $\mathrm{pH}$ point using a digital wireless data acquisition system (FLIR Systems, Extech Instruments, Model EX5422, Inc., USA) linked to a PC. Sediment samples were also collected at each $\mathrm{pH}$ point as the voltage reached a maximum. The heavy metal analysis was carried out via a sequential extraction method, as mentioned above.

\subsection{Biofilm morphology}

Scanning electron microscope (SEM) analysis was performed. Biofilm samples from treated anodes and cathodes were compared with untreated graphite samples (control). The samples were immersed in $0.1 \mathrm{~mol} \mathrm{~L}^{-1}$ cacodylate buffer $(\mathrm{pH}$ $7.4)$ and then also in glutaraldehyde $(2.5 \% \mathrm{w} / \mathrm{v})$. Then, the samples were dehydrated using increasing ethanol concentrations (30\%, 50\%, $70 \%$ and $100 \%)$. A critical-point drier was used to fix dried samples. Then, a sputter-coated $40 \mathrm{~nm}$ gold layer was introduced. The coated samples were observed via SEM (Zeiss, model DSM-960, Germany), and digital images were taken.

\subsection{Microbial characterization}

After 120 days of incubation, the electrodes were dislodged from the surface water and sediments, and sterile freshwater was used to rinse the surfaces of the electrodes. The surfaces of the graphite electrodes were scratched strenuously to about $1 \mathrm{~mm}$ with a sterile razor blade, and the bacterial biomass was put into $10 \mathrm{~mL}$ of sterilized water and serially diluted 10 times. About $1 \mathrm{~mL}$ from each dilution was taken and spread on nutrient agar plates; bacterial colonies were picked based on the morphology and then these colonies were purified on nutrient agar plates. Each bacterial colony was grown into $50 \mathrm{~mL}$ of nutrient broth and this was used for DNA isolation. According to the manufacturer protocol, DNA was extracted via the commercial UltraClean Soil DNA Isolation Kit, Mo Bio (Carlsbad, CA, USA). The universal forward primer Eubac27F (5'-AGAGTTTGATCCTGGCTC AG-3') and the reverse primer 1492R (5'- 
GGTTACCTTGTTAC GACTT-3') were applied to magnify the bacterial 16S rRNA via the PCR method. ${ }^{14}$ A cloning kit (TOPO TA, Carlsbad, Invitrogen, USA) was used with the PCR products. Once the DNA sequences were determined, a similarity search in the NCBI Blast GenBank database was carried out.

\section{Results \& discussion}

\subsection{SMFC voltage output}

The voltage generation from the SMFCs (replicates) over the experimental duration of 120 days is shown in Fig. 2. Both the ASMFC and NA-SMFC started to produce electricity on the first operational day, A-SMFC and NA-SMFC generated $0.60 \mathrm{mV}$ $(0.0006 \mathrm{~mA})$ and $0.38 \mathrm{mV}(0.00038 \mathrm{~mA})$ after loading an external resistance of $1000 \Omega$. A maximum difference of only $0.00022 \mathrm{~mA}$ was noted in the beginning. In the A-SMFCs the voltage increased and reached a maximum value of $580.5 \mathrm{mV}(0.580$ $\mathrm{mA}$ ) between 50 and 60 days, while for the NA-SMFCs, the voltage reached a maximum of $510 \mathrm{mV}(0.51 \mathrm{~mA})$ between 60 and 70 days. The maximum current difference was recorded as being about $0.07 \mathrm{~mA}$ at these voltage points.

Above a certain value, the current output was stable using an external resistance of $1000 \Omega$. Then, the current declined sharply after day 70. Near these turning points, $\mathrm{Cr}$ (III) ions, $\mathrm{Cu}(\mathrm{I})$ ions and $\mathrm{Ni}$ (II) ions were still detected, which suggests that these heavy metals were nearly completely reduced at these turning marks.

The generation of higher voltages by A-SMFCs compared to NA-SMFCs could be ascribed to: (i) the presence of high amounts of dissolved oxygen at the cathode, with an improvement in cathodic potential rather than in cell voltage; (ii) mass transfer to the anode being limited, because large numbers of $\mathrm{H}^{+}$ions moved to the anode chamber from the cathode due to the absence of oxygen, which lowered the $\mathrm{pH}$ of the anode chamber and resulted in a lower concentration of electron donors; and (iii) the earlier adoptability of exoelectrogens to the environment in the A-SMFCs compared to the NA-SMFCs. ${ }^{15}$ This was perhaps due to the consumption of all substrates in the SMFCs by exoelectrogens. Another reason for the high current production in the A-SMFC may be due to the presence of filamentous bacteria detected in SEM analysis, because mostly filamentous bacteria have conductive pili, which are the dominant mechanism in exoelectrogens for electron transfer to the

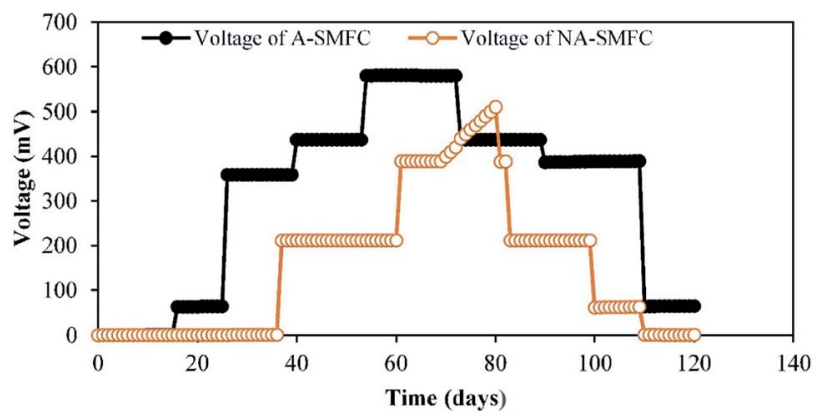

Fig. 2 Voltage generation trends for A-SMFCs and NA-SMFCs. electrodes. Oxidation and reduction phenomena may also be involved in lowering the voltage output due to the production of basic and acidic by-products at both terminals during later operational days. ${ }^{16}$

\subsection{Polarization and internal resistance}

Polarization slopes were plotted to find out the relationship between resistance and current during SMFC operation. Various external resistances from $60 \Omega$ to $2 \mathrm{k} \Omega$ were used to carry out the polarization study, as shown in Fig. $3 a$ and $b$. Current production was negatively correlated to the external resistance values. The same power production trend was observed by Abazarian et al. ${ }^{17}$ for A-SMFCs; when the resistance was increased from $60 \Omega$ to $2 \mathrm{k} \Omega$, the voltage was reduced from $150 \mathrm{mV}(2.5 \mathrm{~mA})$ to $90 \mathrm{mV}(0.0045 \mathrm{~mA})$. Whereas, when the external resistance was reduced from 800 to $100 \Omega$ the voltage speedily increased from $20 \mathrm{mV}(0.025 \mathrm{~mA})$ to $50 \mathrm{mV}(0.5 \mathrm{~mA})$. A maximum power density of $450.5 \mathrm{~mW} \mathrm{~m}^{-2}$ and current density of $0.75 \mathrm{~mA} \mathrm{~m}^{-2}$ were measured in the A-SMFC, at the cell-design point of $2 \mathrm{k} \Omega$ (external resistance), with $900 \Omega$ internal resistance. At lower resistances, the potential stabilization was not quick, but the power generation trend was increasing. The voltage destabilization was very fast at lower resistances, and more stabilized at higher external resistances. The slow potential drop and stabilization at lower resistances may be due to effective electron discharge. At lower resistances, the electrons move more easily through the circuit, giving higher currents and power densities with low stabilization. A polarization curve was also plotted in the case of NA-SMFCs. A maximum power density of $3781.25 \mathrm{~mW} \mathrm{~m}^{-2}$ and current density of $2.752 \mathrm{~mA}$ $\mathrm{m}^{-2}$ were noted at an external resistance of $200 \Omega$. The internal resistance was $550 \Omega$. The NA-SMFCs showed less internal resistance than the A-SMFCs. It has been observed that aeration at the cathode is the main cause for the voltage stabilization at higher resistances. In the A-SMFCs, oxygen was available at the cathode, which helped to increase the cathode reaction rate, resulting in the stabilization of voltage at higher resistances than in NA-SMFCs.

The low availability of oxygen at the cathode terminal results in low stabilization. The difference in internal resistance between A-SMFCs and NA-SMFCs may be due to the pH difference between the anode and cathode compartments. In the case of A-SMFCs, the pH of both chambers was negligible, but in the case of NA-SMFCs, the $\mathrm{pH}$ was important. The optimum $\mathrm{pH}$ in the NA-SMFCs was 3.0 because $\mathrm{H}^{+}$ions diffused from the cathode chamber to the anode chamber, lowering the $\mathrm{pH}$. As the $\mathrm{pH}$ difference between both chambers increased, the internal resistance also decreased. The greater the $\mathrm{pH}$ difference between both chambers, the greater the power density destabilization. ${ }^{\mathbf{1 0}}$

\subsection{Cyclic voltammetry}

The impact of A-SMFC and NA-SMFC electrode exhibited bacterial biomass $(0.5 \mathrm{mg})\left(40^{\text {th }} 80^{\text {th }}\right.$ and $120^{\text {th }}$ days $)$ on voltammetric analysis was determined through characterizing cyclic voltammograms, as shown in Fig. 4a and b. A-SMFCs 

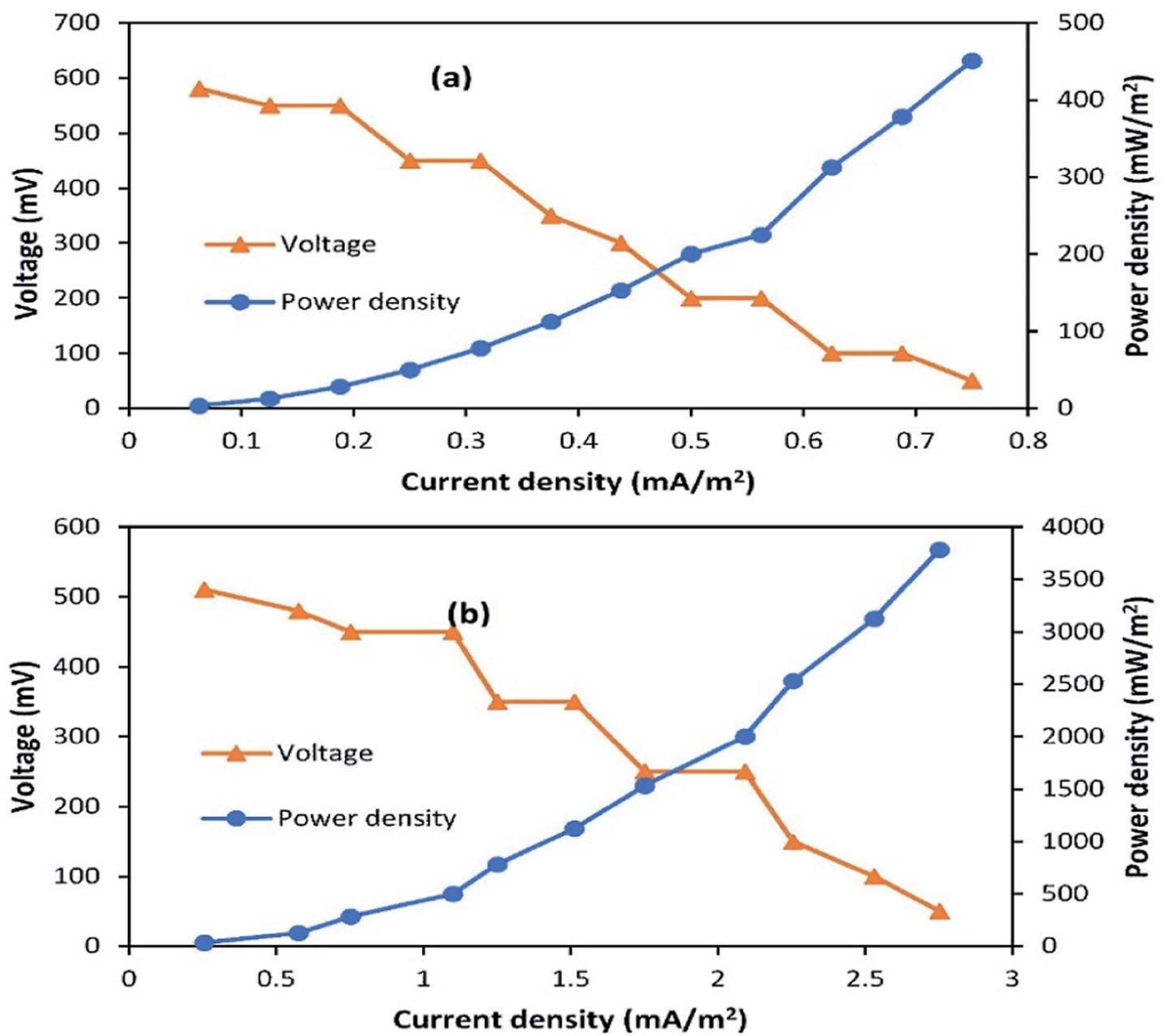

Fig. 3 Polarization plots for (a) A-SMFCs and (b) NA-SMFCs operated over the external resistance range of $60 \Omega$ to $2 \mathrm{k} \Omega$.

showed the following maximum currents in the forward scan: $40^{\text {th }}$ day, $17.11 \mu \mathrm{A} ; 80^{\text {th }}$ day, $25.23 \mu \mathrm{A}$; and $120^{\text {th }}$ day, $14.38 \mu \mathrm{A}$; and the reverse scan: $40^{\text {th }}$ day, $-15.21 \mu \mathrm{A} ; 80^{\text {th }}$ day, $-21.23 \mu \mathrm{A}$; and $120^{\text {th }}$ day, $-11 \mu \mathrm{A}$. NA-SMFCs showed the following maximum currents in the forward scan: $40^{\text {th }}$ day, $13.23 \mu \mathrm{A} ; 80^{\text {th }}$ day, $17.34 \mu \mathrm{A}$; and $120^{\text {th }}$ day, $11.43 \mu \mathrm{A}$; and the reverse scan: $40^{\text {th }}$ day, $-12.54 \mu \mathrm{A} ; 80^{\text {th }}$ day, $-15.32 \mu \mathrm{A}$; and $120^{\text {th }}$ day, $-8.45 \mu \mathrm{A}$. Relatively higher current output was measured during the
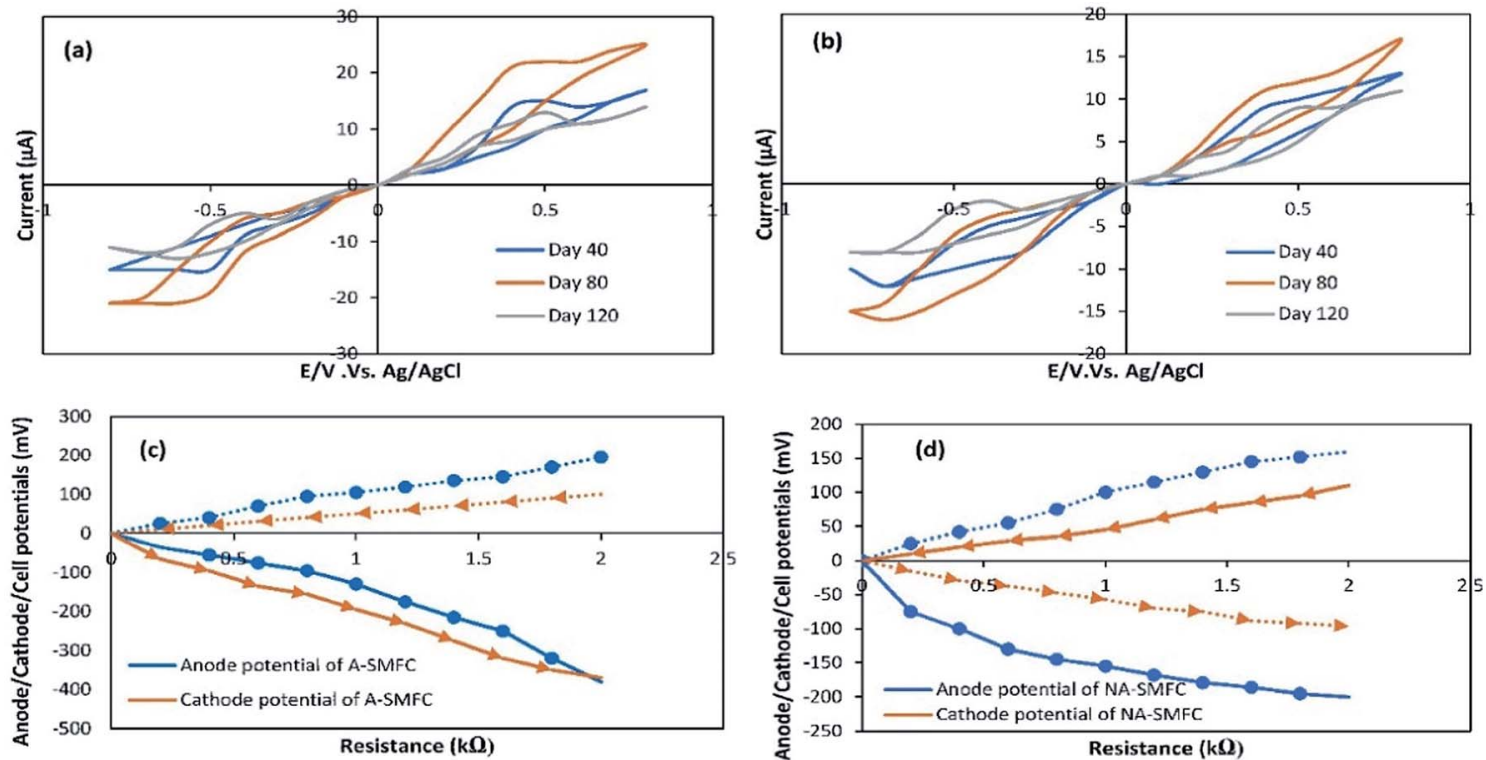

Fig. 4 Cyclic voltammograms for (a) A-SMFCs and (b) NA-SMFCs operating over the range of -0.8 to $+0.8 \mu$ A. Cell potentials (solid lines show cell potentials, dashed dots show anode potentials, and dashed arrows show cathode potentials) for A-SMFCs (c) and NA-SMFCs (d). 
forward scan, irrespective of experimental variation, suggesting higher oxidation rather than reduction.

In both SMFCs, maximum currents in the forward scan and reverse scans were recorded as follows: A-SMFCs: FS, $25.23 \mu \mathrm{A}$; $\mathrm{RS},-21.23 \mu \mathrm{A}$; and NA-SMFCs: FS, $17.34 \mu \mathrm{A}$; RS, -15.32 $\mu \mathrm{A}$. Clear oxidation and redox peaks were recorded for both SMFCs on the $40^{\text {th }}, 80^{\text {th }}$, and $120^{\text {th }}$ days. A-SMFCs and NA-SMFCs showed oxidation peaks on the $40^{\text {th }}\left(E_{\text {oxi }}, 0.41 \mathrm{~V}\right), 80^{\text {th }}(0.52$ $\mathrm{V})$, and $120^{\text {th }}$ days $\left(E_{\text {oxi }}, 0.40 \mathrm{~V}\right)$, and reduction peaks on the $40^{\text {th }}$ $\left(E_{\text {Red }},-0.55 \mathrm{~V}\right), 80^{\text {th }}$ day $\left(E_{\text {Red }},-0.64 \mathrm{~V}\right)$ and $180^{\text {th }}$ days $\left(E_{\text {Red }}\right.$, $-0.43 \mathrm{~V})$. On the $80^{\text {th }}$ day, the voltammogram showed the highest oxidation and reduction peaks, which is attributed to reversible $\mathrm{e}^{-}$transfer with the highest faradic current. The anodic oxidation and cathodic reduction peaks showed single electron transfer on the $80^{\text {th }}$ day with highest current production. The $\mathrm{e}^{-}$transfer to the anode surface from a redox-protein can possibly participate in a mediated electron transfer (MET) mechanism. The highest oxidation and reduction rates in the ASMFCs might be due to the presence of oxygen, which results in high $\mathrm{e}^{-}$discharge and neutralizes $\mathrm{e}^{-}$before reaching the anode. So in the A-SMFCs, there was a negligible change in $\mathrm{pH}$. The presence of glucose in both SMFCs was the main cause of the oxidation peaks. Normally, the voltammogram values increase with time, due to the exoelectrogen density increasing at the electrode. As the exoelectrogen density increases, the amount of metabolites in the feedstock also changes, affecting the capacity and conductivity of the electrolyte solution. So the disturbance caused by the addition of glucose resulting in the extra voltammogram values can be obtained for immobile phase exoelectrogens or those suspended in the physiological marine solution. Not all voltammogram peaks appeared continuously during various tests, thus indicating the presence of different electronic mediators used by electroactive biofilms during SMFC operation. ${ }^{\mathbf{1 8}}$

The variations in the anode, cathode and cell potentials were measured over the range of $60 \Omega$ to $2 \mathrm{k} \Omega$ in both SMFCs, operating under all experimental conditions, as shown in Fig. $4 \mathrm{c}$ and d. The cathode potentials at $2 \mathrm{k} \Omega$ (A-SMFCs: $100 \mathrm{mV}$; and NA-SMFCs: $-110 \mathrm{mV}$ ) show that the current produced during the running of the SMFCs was not only confined by the anode reaction. The anode potentials (at $2 \mathrm{k} \Omega$ : A-SMFCs: $196 \mathrm{mV}$; and NA-SMFCs: $-160 \mathrm{mV}$ ) were significantly decreased upon decreasing the resistance. The anode potential regulates the kinetics of electron transfer from microorganisms

Table 2 The capacitances of the anode and cathode with exoelectrogen colonization on the $40^{\text {th }}, 80^{\text {th }}$ and $120^{\text {th }}$ days

\begin{tabular}{llllll}
\hline & \multicolumn{3}{l}{ Capacitance $\left(\mathrm{F} \mathrm{cm}^{-2}\right)$} & & \\
\cline { 2 - 3 } & Anode & & Cathode & \\
\cline { 2 - 3 } \cline { 5 - 6 } Day & A-SMFC & NA-SMFC & & A-SMFC & NA-SMFC \\
\hline 40 & 1.5 & 1.0 & 0.5 & 0.4 \\
80 & 2.7 & 2.2 & 0.7 & 0.3 \\
120 & 0.7 & 0.4 & 0.3 & 0.1
\end{tabular}

to the anode. The anode potential in both SMFCs decreased below $1 \mathrm{k} \Omega$ and $2 \mathrm{k} \Omega$, suggesting effective electron discharge below these external resistances.

CV curves are shown for the $40^{\text {th }}, 80^{\text {th }}$ and $120^{\text {th }}$ days. Based on these curves, the capacitance values for the anode and cathode were measured, and are shown in Table 2 . The capacitance of the anode was increased more than the cathode on the $40^{\text {th }}$ day (A-SMFC: $1.5 \mathrm{~F} \mathrm{~cm}^{-2}$; NA-SMFC: $1.0 \mathrm{~F} \mathrm{~cm}^{-2}$ ) and the $80^{\text {th }}$ day (A-SMFC: $2.7 \mathrm{~F} \mathrm{~cm}^{-2}$; NA-SMFC: $2.2 \mathrm{~F} \mathrm{~cm}^{-2}$ ) indicating the growth of biofilm on the anode. The capacitance was decreased on the $120^{\text {th }}$ day. As biofilm grew on the anode, the total capacitance of the anode increased by $2.5-4.9 \mathrm{~F} \mathrm{~cm}^{-2}$ for both SMFCs. This increase in anode capacitance is possibly due to the transient charge storage capacity of reductive/oxidative enzymes in the bacterial cytoplasm and on the bacterial cell membrane. ${ }^{19}$ This additional anode capacitance is also due to the acclimatization of exoelectrogens. Hong et $a .^{20}$ reported that at external low resistances with a respective number of oxidative and reductive peaks, new electron transfer pathways, such as new oxidative and redox/enzymes and self-produced mediators, could emerge in SMFCs and increase the capacitance of the anode. This relatively higher anode capacitance led to the elimination of power overshoot over a short time. The higher anode capacitance compared to the cathode capacitance has the advantage of alleviating the power overshoot when the cathode capacitance was insufficient.

\subsection{Electrochemical impedance spectroscopy}

Equivalent circuit model fitting. The ECM was applied in this study to determine the 3 series resistances: anode ( $\left.R_{\text {anode }}\right)$; solution $\left(R_{\mathrm{S}}\right)$; and cathode $\left(R_{\text {cat }}\right)$. It was observed that the SMFC impedance spectra model was reversible among the cathode and anode. ${ }^{21}$ An estimation of the individual impedance of the anode and cathode was used to characterize the related impedance of these components. The analysis was carried out on mature 120 day-biofilm to ensure that this model was correctly fit to latter periods. Previous studies only focus on how impedance varies during the earlier stage of exoelectrogen growth. Fig. 5a and b shows the impedance spectra for the cathode, anode and whole cell. The first junction on the $x$-axis of the Nyquist plot represents the electrolyte solution resistance (whole cell resistance). The electrolyte resistance was $21 \Omega$ and $15 \Omega$ in the A-SMFC and NA-SMFC, respectively. The projected points in the Nyquist model represent the anode resistances of the A-SMFC and NA-SMFC, which were $0.4 \Omega$ and $0.2 \Omega$, respectively. The cathode resistances of the A-SMFC and NASMFC were $35 \Omega$ and $15 \Omega$, respectively. This shows that the cathode and electrolyte impedances were higher than the anode impedance. This model can easily be applied to later SMFC operation to reproduce the results.

The effect of enrichment on the impedance of a SMFC. The Nyquist model was applied to the EIS spectra to determine the electrochemical impedances of both SMFC electrolytes. Fig. 6 shows impedances at operating loads through fitting the experimental data to the Nyquist model. The total impedance values (electrolyte + cathode + anode) after 40 days for the A- 

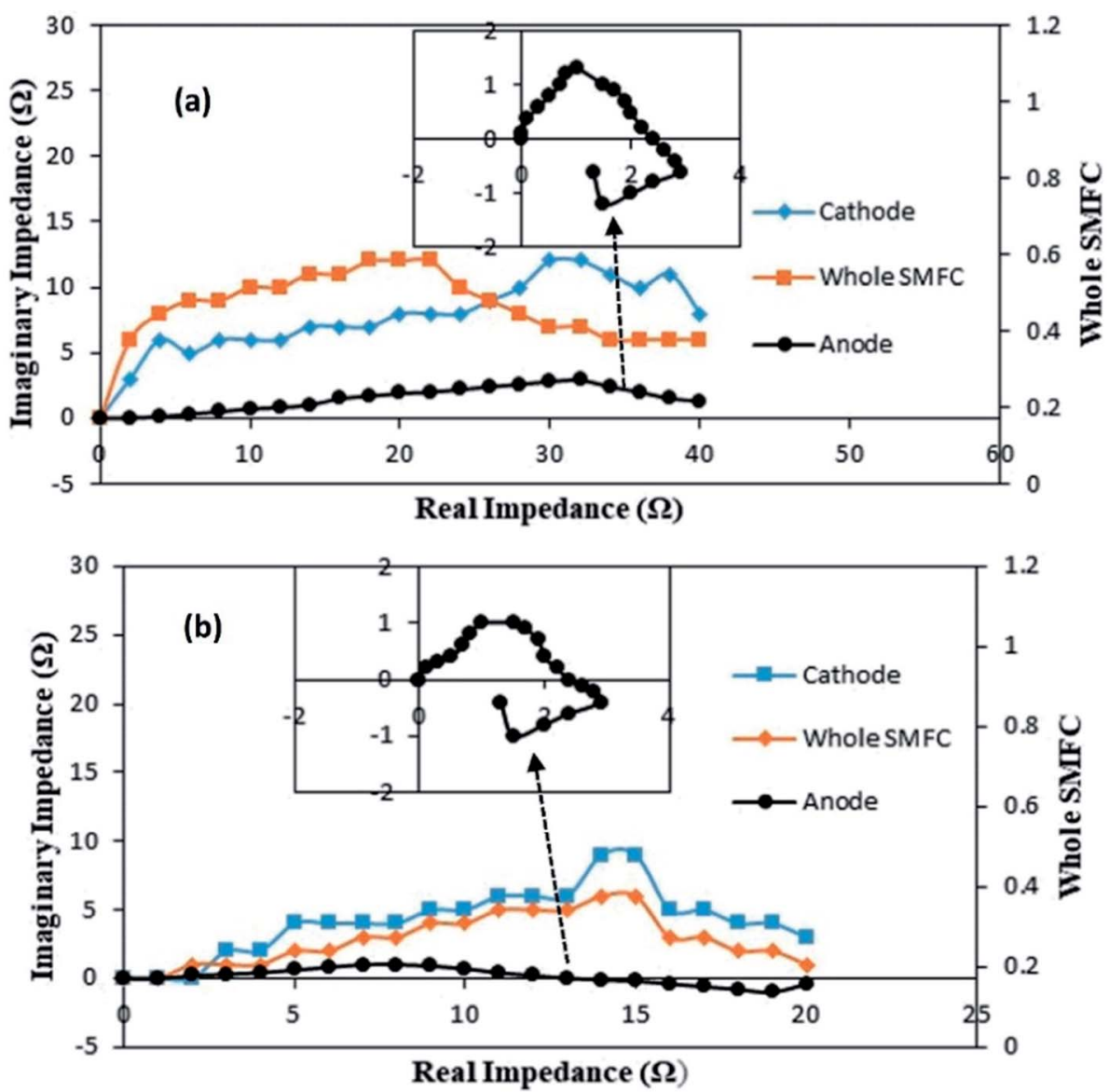

Fig. 5 Nyquist curves for the cathode, anode and whole SMFC: (a) A-SMFC; and (b) NA-SMFC. The insets represent the anode response.

SMFC and NA-SMFC were $70 \Omega$ and $33 \Omega$ (external $R: 200 \Omega$ ). These decreased to $49 \Omega$ in the A-SMFC and $27 \Omega$ in the NASMFC after 120 days (external $R: 100 \Omega$ ).

The individual impedances of the anode, cathode and electrolyte solution dramatically changed, as shown in Fig. 7a and b. The EIS measurements were begun at day 20 with an external $R$ of $50 \Omega$ (A-SMFC: voltage output, $0.160 \mathrm{~V}$; current density, $0.008 \mathrm{~mA} \mathrm{~m}^{-2}$; NA-SMFC: voltage output, $0.100 \mathrm{~V}$; current density, $0.005 \mathrm{~mA} \mathrm{~m}^{-2}$ ).

The total impedance values at day 60 for the A-SMFC and NASMFC were $24.3 \Omega$ and $14.6 \Omega$, respectively. These values

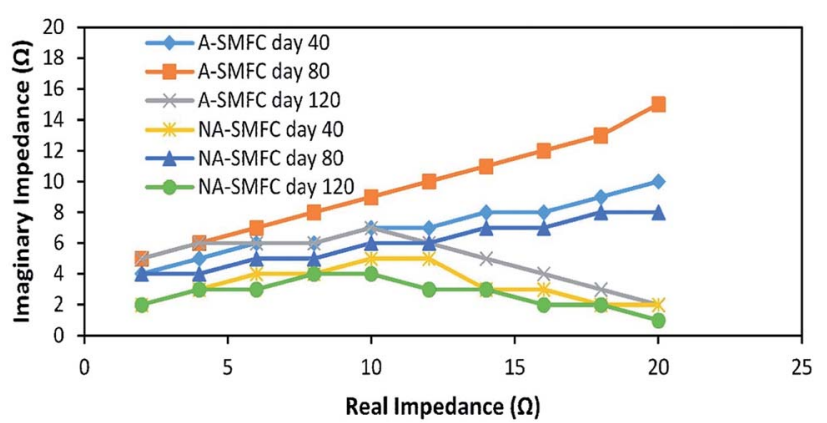

Fig. 6 Nyquist plots indicating EIS data fitted to the ECM model on days 40,80 and 120 for the A-SMFC and NA-SMFC. decreased on day 120 to $18.5 \Omega$ and $6.8 \Omega$. The anode impedance associated with $R_{\text {anode }}$ in both the A-SMFC and NA-SMFC decreased from $10.1 \Omega$ to $4.5 \Omega$ and from $6.1 \Omega$ to $2.1 \Omega$ from day 20 to day 120 . The cathode impedance ( $\left.R_{\text {cathode }}\right)$ was also decreased in both the A-SMFC and NA-SMFC from day 20 to day 120 , from 9.1 to $10.7 \Omega$ and from 5.2 to $2.1 \Omega$, respectively. The decrease in the anode and cathode impedances was most probably due to the enrichment of exoelectrogen biofilm on the electrodes. The same impact of enrichment on electrode impedance was reported by Borole et al. ${ }^{22}$

\subsection{Sediment heavy metal remediation}

Previous studies have found that the aerobic remediation of certain contaminants (organic and inorganic pollutants) could be improved by supplying a solid-state anode (electron acceptor) to bacteria in a SMFC. However, these studies were only focused on in situ remediation using a two chamber MFC consisting of a permeable exchange membrane. This system is not suitable for open environment remediation due to the closed MFC. Both the A-SMFCs and NA-SMFC were run for 120 days. The heavy metal profile, such as for $\mathrm{Cr}(\mathrm{VI})$ and $\mathrm{Cr}(\mathrm{III})$ ions, $\mathrm{Cu}(\mathrm{II})$ and $\mathrm{Cu}(\mathrm{I})$ ions, and $\mathrm{Ni}(\mathrm{II})$ ions, was detected through XPS before SMFC operation, as shown in Fig. 8a-c.

The A-SMFC and NA-SMFC were operated at their optimal external resistances: $2 \mathrm{k} \Omega$ and $200 \Omega$, respectively. The heavy 

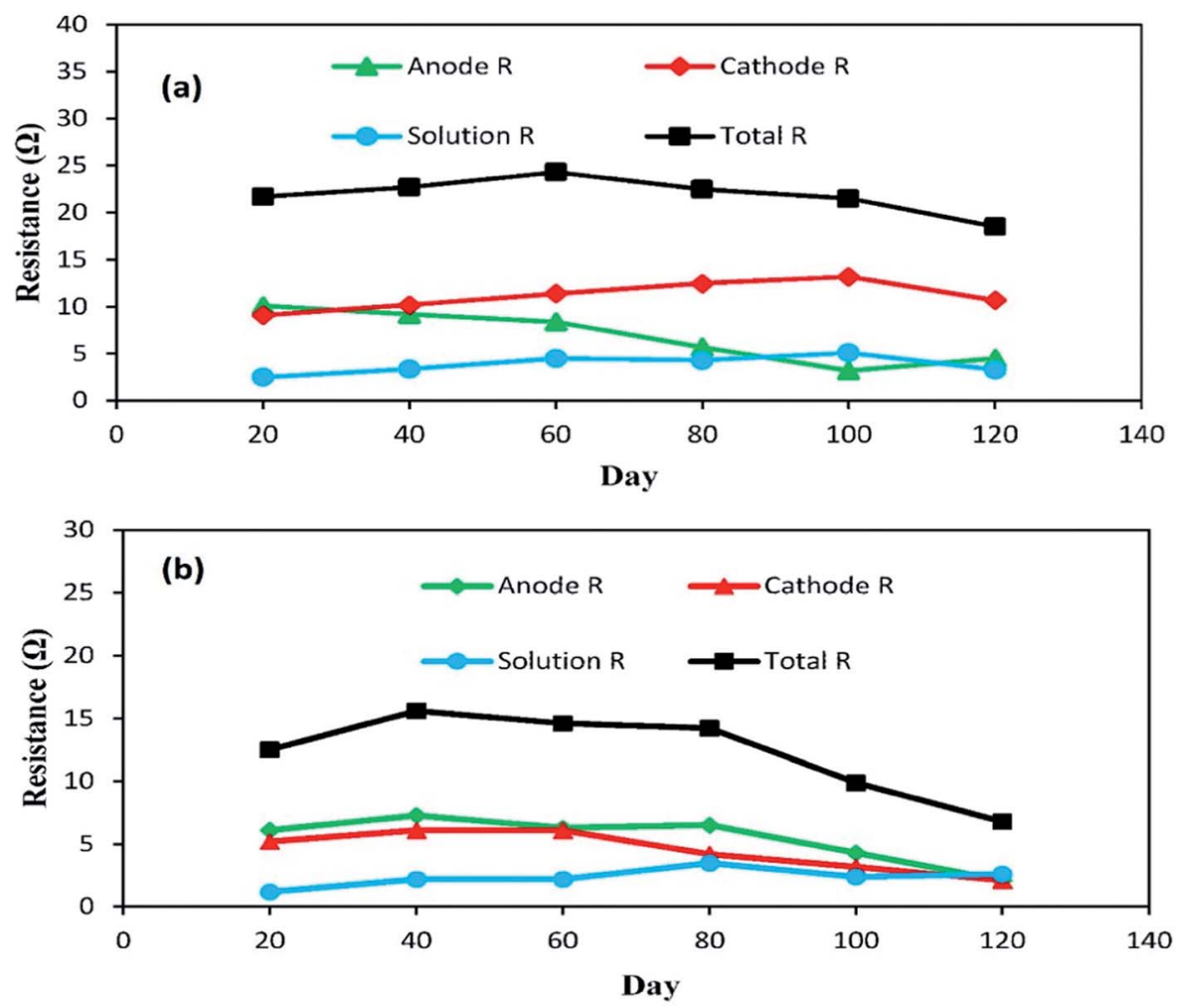

Fig. 7 The behavior of anode, cathode and solution impedances for the (a) A-SMFC and (b) NA-SMFC during the embellishment of exoelectrogenic microbes in SMFCs over time.

metal remediation efficiency was compared with Sediment Management Standards USA, as shown in Table 3. The A-SMFCs reduced a maximum amount of $\mathrm{Cr}(\mathrm{VI})$ ions to $\mathrm{Cr}$ (III) ions, about $80.70 \%$, and $\mathrm{Cu}(\mathrm{II})$ ions to $\mathrm{Cu}(\mathrm{I})$ ions, about $72.72 \%$, and had a maximum uptake of $\mathrm{Ni}(\mathrm{II})$ ions, about $80.37 \%$, after 60 days. The optimum detoxification efficiency using the NA-SMFCs was achieved after 80 days, and was about $67.36 \%$ for $\operatorname{Cr}(\mathrm{vI})$ ions, $59.36 \%$ for $\mathrm{Cu}(\mathrm{II})$ ions, and $52.74 \%$ for $\mathrm{Ni}(\mathrm{II})$ ions.

The detection of less toxic heavy metals ions like Cr(III) ions and $\mathrm{Cu}(\mathrm{I})$ ions after SMFCs operation was achieved via reduction peaks in the cyclic voltammetry studies. Enzymatic redox reactions are normally part of microbial metabolism. $\mathrm{Cr}(\mathrm{vI})$ and $\mathrm{Cu}(\mathrm{II})$ ions can also be reduced at exoelectrogen surfaces via nonmetabolic pathways. Intracellular precipitation is also another mechanism to reduce these metals, but the first one is the dominant reduction mechanism. ${ }^{23} \mathrm{Cr}(\mathrm{VI})$ and $\mathrm{Cu}(\mathrm{II})$ ions are reduced to the less toxic $\mathrm{Cr}(\mathrm{III})$ and $\mathrm{Cu}(\mathrm{I})$ ionic forms in the presence of electron donors like redox-active proteins. $\operatorname{Cr}(\mathrm{VI})$ and $\mathrm{Cu}$ (II) ions are biologically reduced aerobically (A-SMFCs) and anaerobically (NA-SMFCs), but aerobic reduction is dominant because the reduction rate is very slow under anaerobic conditions. The oxygen concentration boosts the rate of reduction. In NA-SMFCs, due to the absence of oxygen, more $\mathrm{CO}_{2}$ is produced via anaerobic fermentation and more $\mathrm{H}^{+}$ions are moved to the anode chamber, raising its $\mathrm{pH}$. So by raising the $\mathrm{pH}$, genes that express the surface binding proteins for $\mathrm{Cr}$ and $\mathrm{Cu}$ are suppressed. In anaerobic bacteria (NA-SMFCs), the toxic effects of heavy metals are associated with a disruption in enzyme structure and function due to metals binding with thiol groups and other groups on protein molecules, or replacing naturally occurring metals in enzyme prosthetic groups. Some studies have proved that the presence of $\mathrm{Cr}, \mathrm{Cu}$ and nickel in sediment mixtures also produced antagonistic and synergistic effects on anaerobic bacteria (NA-SMFCs). ${ }^{24} \mathrm{Ni}(\mathrm{II})$ ions are mostly absorbed inside cells by reducing c-type cytochromes at the surfaces of exoelectrogens and transferring the electrons to the electrodes. OmcT, OmcB, OmcS, OmcZ, OmcF, OmpB and OmpC are dominant c-type cytochromes present at the surfaces of exoelectrogens. ${ }^{25}$ In anaerobic bacteria (NA-SMFCs), nickel stress activates bacterial intracellular detoxification genes, which are mostly located on plasmids. Intracellular defense systems also mediate chelation, bio-methylation and exocytosis in anaerobic bacteria for nickel absorption. ${ }^{26}$

These heavy metal remediation efficiencies fulfill the standards for sediments determined by Sediment Management Standards USA. The remediation efficiencies were lower in the earlier days due to worse adjustment with the environment, and decreased in the last days of operation, very likely as a consequence of the consumption of substrates for microbial metabolism. In the last operational days, electrons were only produced in the cathode chamber and they were transferred to the anode chamber, which altered the $\mathrm{pH}$ of the anode chamber and finally lowered the remediation efficiency of the exoelectrogens. This decrease in $\mathrm{pH}$ might also be due to the fermentation of organic matter in the sediment. The heavy metal reduction rate decreased with time due to the specific 

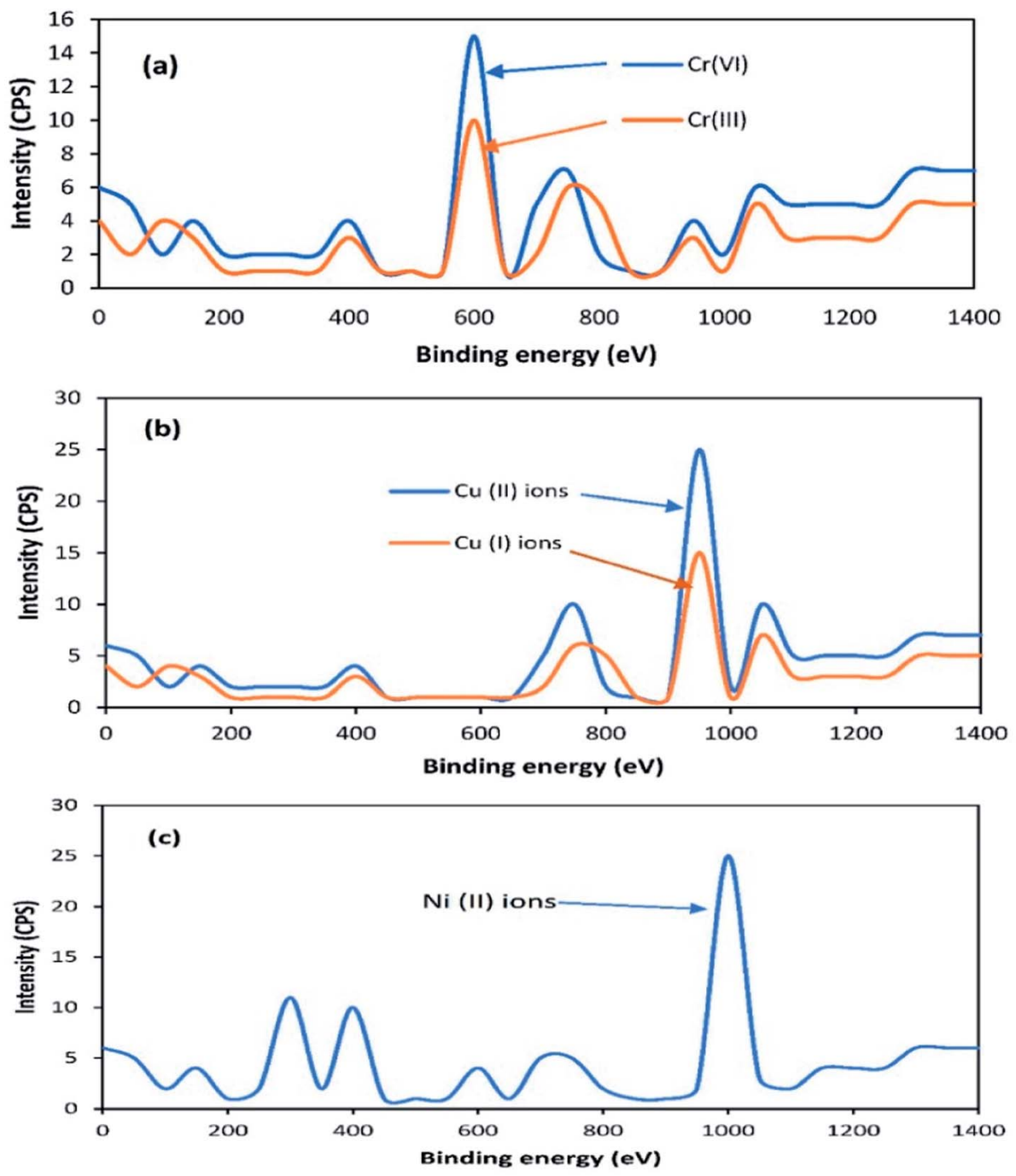

Fig. 8 X-ray photoelectron spectra of $\mathrm{Cr}(\mathrm{a}), \mathrm{Cu}(\mathrm{b})$ and $\mathrm{Ni}$ (c).

growth patterns of bacteria. The bacteria entered into the death phase after a specific time and then the number of dead bacteria was greater than the number of those alive, so the reduction rate of heavy metals decreased with time. Zhang et al. ${ }^{27}$ detoxified copper at about $99.9 \%$ during a catholyte reaction, with a maximum power density of $7.2 \mathrm{~W} \mathrm{~m}^{-2}$ but they used synthetic copper solution, which may render a problem for microbes trying to combat the natural environment, due to the presence of other compounds. Wang $e t a l .{ }^{28}$ reported that external resistances influenced the reduction of $\mathrm{Cr}(\mathrm{Iv})$, the formation of biofilm on electrodes and power generation, and therefore the overall performance of SMFCs. ${ }^{27}$ Previous research also reported that environmental factors like $\mathrm{pH}$, as mentioned above, and external resistances strongly influenced the biological remediation of contaminated sediments. ${ }^{29}$ So to optimize SMFC performance, the influence of these factors on bioremediation and power generation should be addressed in the future.

\subsection{Effect of $\mathrm{pH}$ on the performance of SMFCs}

The effects of $\mathrm{pH}$ on voltage generation and heavy metal reduction are shown in Fig. 9. In the acidic pH range (1.0-6.0), A-SMFCs reduced about $10-55 \%$ of $\mathrm{Cr}(\mathrm{VI})$ ions to $\mathrm{Cr}(\mathrm{III})$ ions, 9$50 \%$ of $\mathrm{Cu}(\mathrm{II})$ ions to $\mathrm{Cu}(\mathrm{I})$ ions, and $5-45 \%$ of $\mathrm{Ni}(\mathrm{II})$ ions, with power generation of $20-360 \mathrm{mV}$. In the basic $\mathrm{pH}$ range (8.013.0), A-SMFCs reduced about $20-50 \%$ of $\mathrm{Cr}(\mathrm{VI})$ ions to $\mathrm{Cr}(\mathrm{III})$ ions, $15-45 \%$ of $\mathrm{Cu}(\mathrm{II})$ ions to $\mathrm{Cu}(\mathrm{I})$ ions, and $13-41 \%$ of $\mathrm{Ni}(\mathrm{II})$ ions, with power generation of $50-410 \mathrm{mV}$. The NA-SMFCs showed a reduction of $5-35 \%$ of $\mathrm{Cr}(\mathrm{VI})$ ions to $\mathrm{Cr}(\mathrm{III})$ ions, 7$38 \%$ of $\mathrm{Cu}(\mathrm{II})$ ions to $\mathrm{Cu}(\mathrm{I})$ ions, and $3-42 \%$ of $\mathrm{Ni}(\mathrm{II})$ ions, with power generation of $10-280 \mathrm{mV}$ in the acidic $\mathrm{pH}$ range. The NASMFCs reduced about $4-45 \%$ of these heavy metals with $30-$ $320 \mathrm{mV}$ power production in the basic $\mathrm{pH}$ range. Both SMFCs showed maximum heavy metal reduction and power generation at $\mathrm{pH}$ 7.0.

So the exoelectrogens in both SMFCs were neutrophils. The microbes in both SMFCs can easily tolerate acidic $\mathrm{pH}$ values of about 1.0-6.0, but their metabolic activities are low. Venkhata 
Table 3 Performances of A-SMFCs and NA-SMFCs for the remediation of heavy metals compared with Sediment Management Standards USA

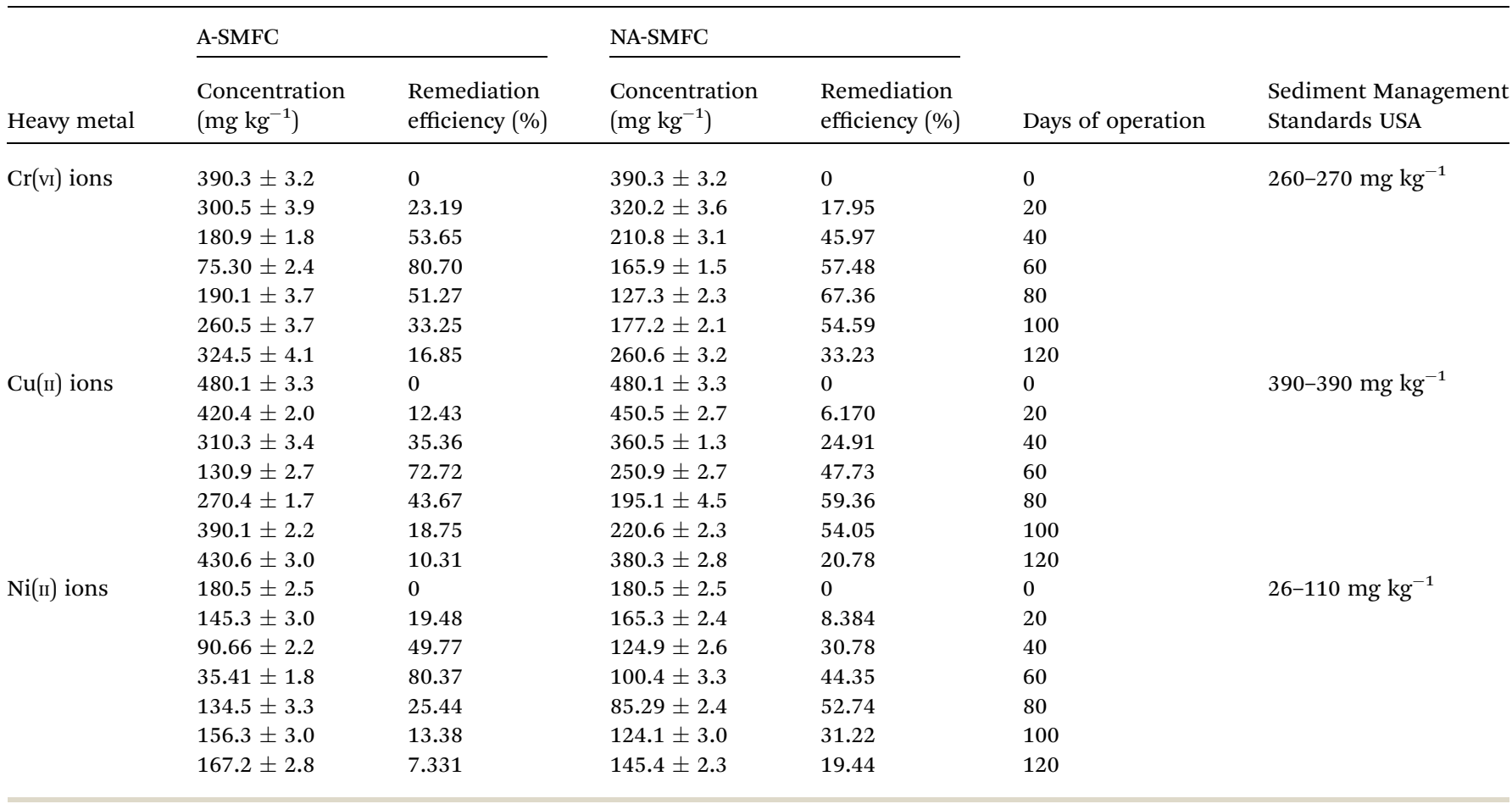

Mohan et $a .^{30}$ reported that acidic $\mathrm{pH}$ values affect SMFC organisms by affecting the substrate metabolism, resulting in $\mathrm{H}^{+}$ion and $\mathrm{e}^{-}$release. Exoelectrogens under acidic conditions are more susceptible to methanogenic metabolism, due to the combination of $\mathrm{H}^{+}$ions and $\mathrm{e}^{-}$with $\mathrm{CO}_{2}$, forming methane. So a neutral $\mathrm{pH}$ suppresses the methanogenic activity, increasing
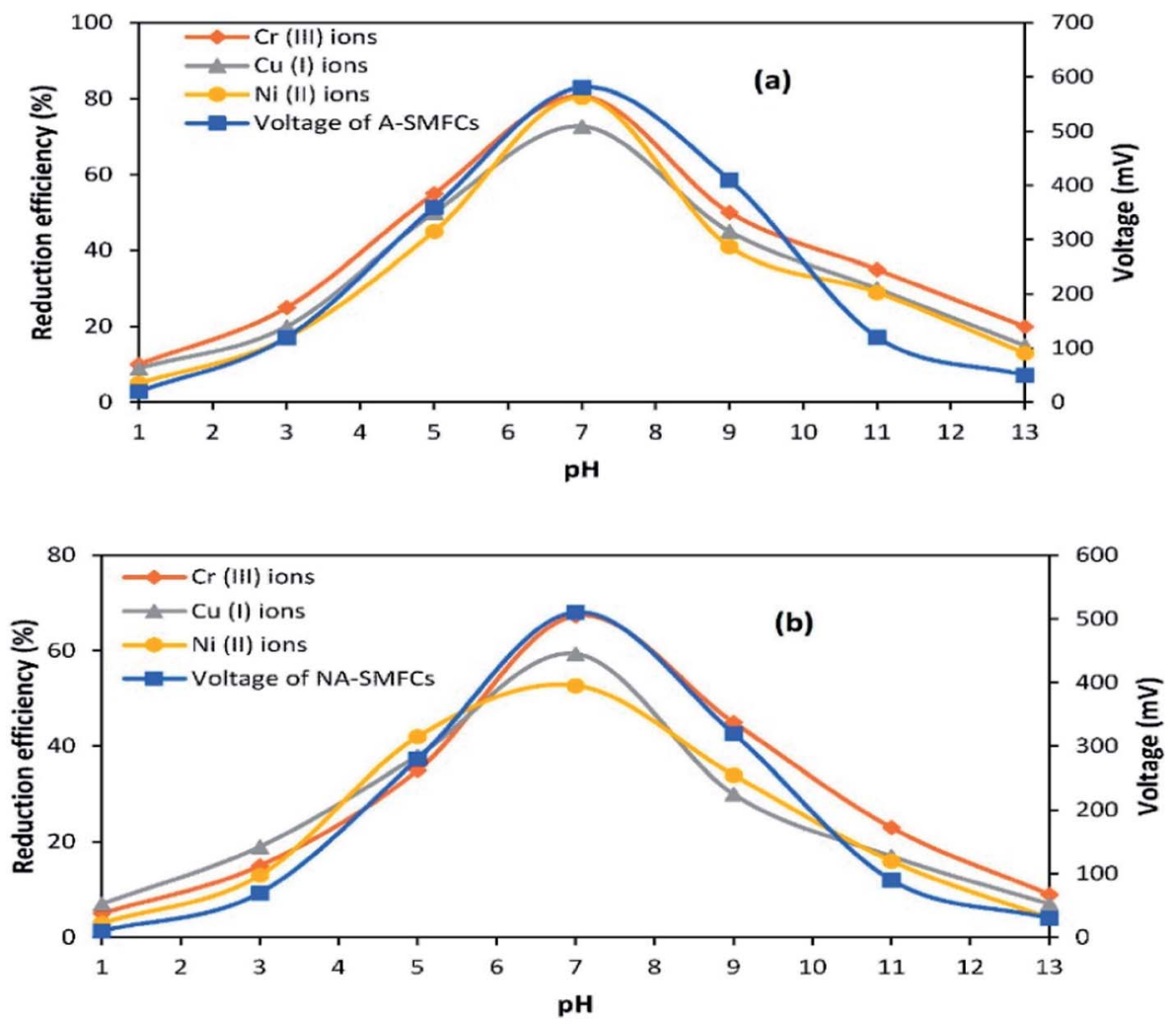

Fig. 9 The effects of $\mathrm{pH}$ on the performance of SMFCs: (a) A-SMFCs; and (b) NA-SMFCs. 

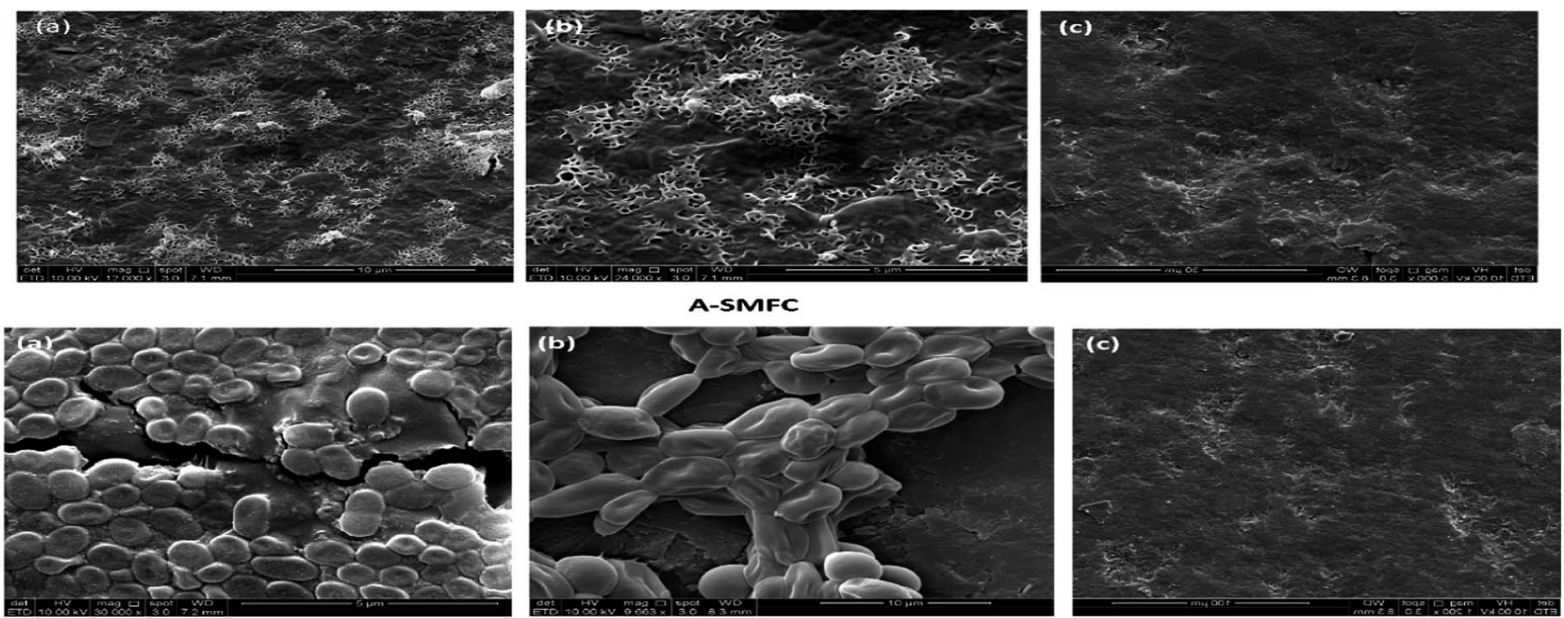

NA-SMFC

Fig. 10 Scanning electron micrograph images taken on day 120 from A-SMFCs and NA-SMFCs: (a) anode graphite; (b) cathode graphite; and (c) untreated graphite.

Table 4 Summary of $16 \mathrm{~S}$ rRNA gene sequences recovered from the $\mathrm{NCBI}$ clone library for electrodes in the A-SMFCs and NA-SMFCs

\begin{tabular}{lll}
$\begin{array}{l}\text { Accession no. of } 16 \mathrm{~S} \\
\text { rRNA gene }\end{array}$ & Name of bacterium & $\begin{array}{l}\text { Percentage } \\
\text { homology }\end{array}$ \\
\hline
\end{tabular}

\section{Anodic bacterial community}

A-SMFC

NR_115756.1

JN377592.1

DQ839562.1

NR_025455.1

CP002159.1

NA-SMFC

LT556085.1

FN433034.1

DQ490332.1

EU652047.1

EF599310.1

Sideroxydans lithotrophicus
Gallionellaceae bacterium
Candidatus nitrotoga
Propionivibrio limicola
Gallionella capsiferriformans
Citrobacter sp. strain 92
Citrobacter farmeri
Enterobacteriaceae bacterium
Pseudomonas stutzeri strain aa-28
Gamma proteobacterium B12

$100 \%$

$98 \%$

$97 \%$

$93 \%$

$93 \%$

$99 \%$

$99 \%$

$99 \%$

$99 \%$

$99 \%$

Cathodic bacterial community

A-SMFC

CP002917.1

GU735087.1

NR_102486.1

AJ627387.1

NA-SMFC

JX458392

U87773.1

HM136777.1

JX219400.1

$\begin{array}{ll}\text { Corynebacterium variabile } & 99 \% \\ \text { Thioalkalivibrio sp. } & 89 \% \\ \text { Thioalkalivibrio nitratireducens } & 89 \% \\ \text { Methylocaldum szegediensis } & 89 \% \\ & \\ \text { Bosea sp. } & 99 \% \\ \text { Afipiageno sp. } & 99 \% \\ \text { Bradyrhizobiaceae bacterium } & 98 \% \\ \text { Starkeya sp. } & 99 \%\end{array}$

the metabolic rate of exoelectrogens, resulting in the generation of high power. García-Muñoz et al. ${ }^{31}$ also reported higher power generation trends at a neutral $\mathrm{pH}$ : about $505.5 \mathrm{mV}$. Yuan et al. ${ }^{32}$ also reported higher exoelectrogen biofilm activity at neutral $\mathrm{pH}$. They noted that a larger number of bacteria attached to the anode at neutral $\mathrm{pH}$, rather than at acidic or basic $\mathrm{pH}$.

\subsection{Biofilm morphology}

SEM images of the mixed cultures on the electrodes show the dispersed and dense cultures of exoelectrogens compared with untreated graphite, as shown in Fig. 10.

The morphologies of the mixed cultures on the aerated anode and cathode took the form of filamentous shaped cells, while the non-aerated anode and cathode were loaded with rodshaped exoelectrogens. Many previous studies reported SEM images of electrode biofilms. ${ }^{33}$ However, very few studies have reported the presence of filamentous appendages in the biofilms of electrodes. Many factors can be the cause of this contradiction. First, there may be a difference in the operating conditions of SMFCs, such as the presence of inorganic substrates, organic ingredients and microbial inoculum. Second, the high SEM resolution may detect the conducting wires in the metals being reduced and the power generating Shewanella and Geobacter species. ${ }^{34}$ From this study we can formulate the hypotheses that these conducting appendages are not necessary for electron transfer to the electrodes, especially to the anode, because other mechanisms like electron redoxactive shuttles are also responsible for electron conduction, but these conducting pili affect the rate of electron transfer and the dominant mechanism in the exoelectrogens.

\subsection{Electro-microbiology}

The diversity of bacterial exoelectrogens in the A-SMFCs and NA-SMFCs, as shown in Table 4, is an encouraging sign that SMFC technology may be fruitful for the remediation of a wide range of heavy metals and power generation. The anodes of both A-SMFCs and NA-SMFCs mostly consist of Proteobacteria strains. Sideroxydans lithotrophicus is an exoelectrogen and a metal reducing bacterium, as previously reported by Shi et al. ${ }^{35}$ Proteobacteria are mostly fermenting bacteria and are most suitable for electricity production and heavy metal remediation. ${ }^{36}$ The cathodes of A-SMFCs and NA-SMFCs mostly contained Actinobacteria and Proteobacteria. It is necessary to note 
that not all exoelectrogen bacteria interact with electrodes as electron acceptors; they also interact with each other in interspecies electron transfer and enhance the performances of SMFCs. These bacteria help in disposing the inhibitory byproducts produced by fermentation. The more diversified microbes in SMFCs produce more power, due to the availability of redox mediators like c-cytochromes (omcZ omcB, omcS, omcT, omcE and omcZL). ${ }^{37}$ Thioalkalivibrio sp. was also reported in this study and it is a suitable exoelectrogen and suitable for heavy metal detoxification due to its production of the cytochrome $\mathrm{cbb}_{3} .^{38}$

16S rRNA gene sequences are ideal to characterize multiple conserved metabolic functions. Bundles of clones with high similarity to bacteria are capable of heavy metal oxidation/ reduction. This represents a sign of the significant preference for the oxidation/reduction of heavy metals by the diverse electrode bacterial community, and backs the hypothesis that the oxidation/reduction of heavy metals in SMFCs by the bacterial community is a default metabolic pathway.

\section{Conclusions}

The focus of this study is to compare the performances of ASMFCs and NA-SMFCs in terms of power generation and heavy metal remediation. The other aim is to optimize parameters such as external and internal resistance, capacitance, electrochemical impedance and construction design to enhance the performances of both A-SMFC and NA-SMFCs. The results indicate that the identified bacteria could transfer electrons to the electrodes to promote power generation and the oxidation/ reduction of heavy metals. Furthermore, the amount of electricity produced by the SMFCs could be used efficiently to power minute monitoring devices in addition to enhancing the remediation of contaminant sediments. However, insufficient clues are present to confirm the exact mechanisms of the oxidation/reduction of heavy metals. Further studies into the electrotrophs (microbes that accept electrons from the electrodes) will be more useful to understand the exact mechanisms of the oxidation/reduction of heavy metals.

\section{Conflicts of interest}

We declare that we have no conflicts of interest.

\section{Acknowledgements}

The authors would like to express their appreciation to the Universiti Sains Malaysia Global Fellowship (USMGF) and RUI grant (1001/PTEKIND/8011044) for the support and research facilities for this project.

\section{References}

1 A. Schievano, A. Colombo, M. Grattieri, S. P. Trasatti, A. Liberale, P. Tremolada, C. Pino and P. Cristiani, J. Power Sources, 2017, 340, 80-88.
2 N. Jannelli, R. A. Nastro, V. Cigolotti, M. Minutillo and G. Falcucci, Appl. Energy, 2017, 192, 543-550.

3 C. Xia, M. Xu, J. Liu, J. Guo and Y. Yang, Bioresour. Technol., 2015, 190, 420-423.

4 L. Hsu, A. Mohamed, P. T. Ha, J. Bloom, T. Ewing, M. AriasThode, B. Chadwick and H. Beyenal, J. Electrochem. Soc., 2017, 164, H3109-H3114.

5 S. Bajracharya, M. Sharma, G. Mohanakrishna, X. D. Benneton, D. P. Strik, P. M. Sarma and D. Pant, Renewable Energy, 2016, 98, 153-170.

$6 \mathrm{X} . \mathrm{Xu}, \mathrm{Q}$. Zhao, M. Wu, J. Ding and W. Zhang, Bioresour. Technol., 2017, 225, 402-408.

7 Q. Wang, L. Huang, Y. Pan, X. Quan and G. L. Puma, J. Hazard. Mater., 2017, 321, 896-906.

8 D. Frattini, G. Falcuccia, M. Minutilloa, C. Feronea, R. Cioffia and E. Jannellia, Chem. Eng. Trans., 2016, 49, 85-90.

9 C. E. Reimers, L. M. Tender, S. Fertig and W. Wang, Environ. Sci. Technol., 2001, 35, 192-195.

10 T. Sajana, M. Ghangrekar and A. Mitra, J. hazard. toxic radioact., 2016, 21, 04016022.

11 B. E. Logan, Microbial fuel cells, John Wiley \& Sons, 2008.

12 D. Yu, L. Bai, J. Zhai, Y. Wang and S. Dong, Talanta, 2017, 168, 210-216.

13 Sediment Management Standards, Department of Ecology State of Washington: chapter 173-204 WAC, Effective September 2013.

14 S. Z. Abbas, M. Rafatullah, N. Ismail and J. Lalung, Desalin. Water Treat., 2015, 56, 1037-1046.

15 D. Zhu, D.-B. Wang, T.-s. Song, T. Guo, P. Wei, P. Ouyang and J. Xie, Biotechnol. Lett., 2016, 38, 271-277.

16 S. Z. Abbas, M. Rafatullah, N. Ismail and M. I. Syakir, Int. J. Energy Res., 2017, 41, 1242-1264.

17 E. Abazarian, R. Gheshlaghi and M. A. Mahdavi, J. Power Sources, 2016, 325, 739-744; T. Sajana, M. Ghangrekar and A. Mitra, J. hazard. toxic radioact., 2016, 21, 04016022.

18 L. Liu, T.-Y. Chou, C.-Y. Lee, D.-J. Lee, A. Su and J.-Y. Lai, Int. J. Hydrogen Energy, 2016, 41, 4504-4508.

19 X. Peng, H. Yu, H. Yu and X. Wang, Bioresour. Technol., 2013, 138, 353-358.

20 Y. Hong, D. F. Call, C. M. Werner and B. E. Logan, Biosens. Bioelectron., 2011, 28, 71-76.

21 S. Chen, J. Tang, L. Fu, Y. Yuan and S. Zhou, J. Soils Sediments, 2016, 16, 2326-2334.

22 A. P. Borole, D. Aaron, C. Y. Hamilton and C. Tsouris, Environ. Sci. Technol., 2010, 44, 2740-2745.

$23 \mathrm{M} . \mathrm{Wu}, \mathrm{X} . \mathrm{Xu}, \mathrm{Q}$. Zhao and Z. Wang, $R S C A d v ., 2017,7$, 53433-53438.

24 Y. Chen, J. J. Cheng and K. S. Creamer, Bioresour. Technol., 2008, 99, 4044-4064.

25 T.-s. Song, Y. Jin, J. Bao, D. Kang and J. Xie, J. Hazard. Mater., 2016, 317, 73-80.

26 B. Song, G. Zeng, J. Gong, J. Liang, P. Xu, Z. Liu, Y. Zhang, C. Zhang, M. Cheng and Y. Liu, Environ. Int., 2017, 105, 43-55.

27 D. Zhang, J. Wang, J. Zhao, Y. Cai and Q. Lin, Geomicrobiol. J., 2016, 33, 318-324. 
28 C. Wang, H. Deng and F. Zhao, Soil Sediment Contam, 2016, 25, 1-12.

29 S. Z. Abbas, M. Rafatullah, N. Ismail and R. A. Nastro, Int. J. Energy Res., 2017, 41, 2345-2355.

30 S. V. Mohan, S. Srikanth, S. V. Raghuvulu, G. Mohanakrishna, A. K. Kumar and P. Sarma, Bioresour. Technol., 2009, 100, 2240-2246.

31 J. García-Muñoz, V. M. Fernández, A. L. De Lacey, M. Malki and R. Amils, Int. Microbiol., 2011, 14, 73-81.

32 Y. Yuan, B. Zhao, S. Zhou, S. Zhong and L. Zhuang, Bioresour. Technol., 2011, 102, 6887-6891.

33 H.-M. Zhang, W. Xu, G. Li, Z.-M. Liu, Z.-C. Wu and B.-G. Li, Sci. Rep., 2016, 6, 21059.
34 P. D. Kiely, D. F. Call, M. D. Yates, J. M. Regan and B. E. Logan, Appl. Microbiol. Biotechnol., 2010, 88, 371-380.

35 L. Shi, H. Dong, G. Reguera, H. Beyenal, A. Lu, J. Liu, H.-Q. Yu and J. K. Fredrickson, Nat. Rev. Microbiol., 2016, 14, 651-662.

36 J. Kan, L. Hsu, A. C. Cheung, M. Pirbazari and K. H. Nealson, Environ. Sci. Technol., 2010, 45, 1139-1146.

37 T. Ewing, P. T. Ha and H. Beyenal, Appl. Energy, 2017, 192, 490-497.

38 M. S. Muntyan, D. A. Cherepanov, A. M. Malinen, D. A. Bloch, D. Y. Sorokin, I. I. Severina, T. V. Ivashina, R. Lahti, G. Muyzer and V. P. Skulachev, Proc. Natl. Acad. Sci. U. S. A., 2015, 112, 7695-7700. 